\title{
DWIKEWARGANEGARAAN ETNIS TIONGHOA DI LUAR TIONGKOK: \\ SUATU ANALISIS TERHADAP PERSPEKTIF PEMERINTAH TIONGKOK
}

\author{
Joanessa M.J.S. Seda
}

\begin{abstract}
The paper is about the historical efforts made by the Chinese Qing dynasty up to the current government to bond the Chinese overseas throughout the world to funnel their financial gain to the homeland. It shows that the policy to take advantage of the Chinese overseas to send their revenues to develop China, was adopted even during the nationalist governments. However, the analysis poses the strong reason of the tie of the Chinese overseas to the homeland, that it was not only given just for its financial support, but that it has been generated by a strong sense of cultural connectedness. On the other hand, although, culturally, the Chinese are attached to their cultural heritage, efforts to force the Chinese overseas to continually support the homeland were not that successful. In the nineteenth century, the Chinese in Indonesia during the colonial time, have been granted by the emperor, a double citizenship. But after the Mao downfall, some of the Southeast Asia countries, including Indonesia, has opposed communism in the region, thus rejected the policy. The republic of Deng finally revoked the doublecitizenship policy and as a result, encouraged promotion of teaching Chinese language overseas and sending scholars to study abroad.
\end{abstract}

\section{Keywords}

Double-citizenship law, mainland China, plantation workers during the Dutch colonial time, ChineseIndonesian ethnic, Chinese language training for teachers, sending Chinese scholars abroad.

\section{PENGANTAR}

Berbicara mengenai perundang-undangan dan etnis Tionghoa di Indonesia tidak mungkin terlepas dari pembicaraan mengenai dwi kewarganegaraan beserta Undang-Undang dan kebijakan yang berkaitan dengannya. Soal dwikewarganegaraan etnis Tionghoa ini bukan hanya seringkali menjadi masalah interen antara Pemerintah Indonesia dan etnis Tionghoa setempat, tetapi juga dalam hubungan antara Pemerintah Indonesia dan Pemerintah Tiongkok yang mencapai titik kulminasinya pada periode 1949-1955. Sesungguhnya mencuatnya masalah ini disebabkan pemberlakuan regulasi, kebijakan, dan Undang-Undang Kewarganegaraan, baik oleh Pemerintah di Tiongkok maupun oleh Pemerintah di Indonesia, yang sama-sama mengklaim etnis Tionghoa 
sebagai warga negara mereka masing-masing. Akibatnya, terjadi benturan kepentingan, terutama dalam bidang ekonomi dan politik, antara Pemerintah di Indonesia dan Pemerintah di Tiongkok sehubungan dengan keberadaan etnis Tionghoa di luar Tiongkok. Makalah ini hanya menyoroti soal dwikewarganegaraan etnis Tionghoa di luar Tiongkok dari sudut pandang Pemerintah Tiongkok dengan berfokus pada dua hal. Pertama, pada faktor-faktor apa saja yang mendorong Pemerintah Tiongkok untuk menetapkan regulasi, kebijakan, serta Undang-Undang yang mengklaim etnis Tionghoa di luar Tiongkok sebagai warga negara sekaligus bagian dari bangsanya. Kedua, pada sejarah perkembangan hukum dan kebijakan Pemerintah Tiongkok yang berkaitan dengan etnis Tionghoa di luar Tiongkok.

\section{LATAR BELAKANG DAN LAHIRNYA REGULASI KEWARGANEGARAAN DINASTI QING}

Faktor awal yang melatarbelakangi lahirnya regulasi kewarganegaraan Dinasti Qing ialah menurunnya kondisi dalam negeri Kekaisaran Tiongkok yang disertai dengan melemahnya kekuasaan Dinasti Qing ${ }^{1}$ pada abad 19. Adanya faktor ketidakseimbangan antara laju peningkatan populasi dan jumlah lahan yang subur serta maraknya bencana alam, korupsi dan menurunnya militer Dinasti Qing yang ditambah dengan masuknya kekuatan-kekuatan Barat ke Tiongkok, membuat kondisi dalam negeri Kekaisaran Tiongkok semakin parah. Terbukanya kesempatan bagi kekuatan-kekuatan Barat untuk membagi-bagi wilayah kedaulatan Kekaisaran Tiongkok melalui hak-hak istimewa yang mereka peroleh, pada akhirnya menyebabkan Tiongkok jatuh menjadi negara semi-koloni. Melihat keadaan dalam negerinya yang demikian terpuruk, pemerintah Dinasti Qing melakukan gerakan modernisasi dalam berbagai bidang, dengan belajar dari Barat, guna memperbaiki kondisi dalam negerinya sekaligus memperkuat kembali kekuasaan dinastinya. Untuk itu, Pemerintah Dinasti Qing memerlukan bantuan dari berbagai pihak, tetapi terutama dari orang-orang Tionghoa yang tinggal sementara atau yang sudah menetap seterusnya di luar Kekaisaran Tiongkok, tepatnya di kawasan "Laut Selatan" (Nanyang)2 (南洋), yang kini dikenal sebagai kawasan Asia Tenggara.

Orang-orang Tionghoa yang menetap di kawasan "Laut Selatan" umumnya berasal dari propinsi Fujian dan Guangdong. Mereka mulai menetap di wilayah tersebut sejak abad ke-3 Masehi untuk berdagang dan kemudian juga sebagai tenaga kuli di sejumlah perkebunan, pertambangan serta pembangunan jalan raya, jalur kereta api

\footnotetext{
${ }^{1}$ Dinasti Qing (1644-1912) didirikan oleh Suku Bangsa Man (Manzu) yang masih merupakan keturunan Suku Bangsa Nunzhen yang mendiami wilayah Timur Laut Tiongkok. Chinese History. Beijing: China Reconstructs Press. 1988. 150.

2 "Laut Selatan" (Nanyang) mengacu pada daerah-daerah di kawasan Laut Cina Selatan, yang dicapai oleh orang-orang Cina melalui jalur pelayaran. Daerah-daerah yang dimaksud ialah wilayah pantai dari dataran Asia Tenggara serta sebagian besar kepulauan Filipina dan Indonesia. Wang Gungwu, Community and Nation: China, Southeast Asia and Australia, Allen \& Unwin Pty, Ltd. 1992. 11.
} 
dan pelabuhan di Hindia-Belanda dan Malaya. Mereka membaur dengan masyarakat setempat sehingga akhirnya membentuk komunitas-komunitas keturunan Tionghoa yang masih tetap memelihara nilai-nilai tradisi dan budaya Tionghoa serta masih memiliki ikatan dengan negeri leluhur mereka. Arus perpindahan etnis Tionghoa ke wilayah "Laut Selatan" makin meningkat dengan maraknya pengiriman dana remitensi ${ }^{3}$ oleh etnis Tionghoa di kawasan "Laut Selatan" ke famili mereka di Tiongkok serta berkat kesuksesan yang diraih etnis Tionghoa tersebut dalam bidang usaha yang mereka jalankan. Bagi etnis Tionghoa yang pindah menetap di wilayah "Laut Selatan" ini, kepindahan mereka keluar dari Tiongkok membawa keuntungan tersendiri karena dengan bekerja di perkebunan, pabrik serta pertambangan milik Pemerintah kolonial Barat, sehingga etnis Tionghoa tersebut berkesempatan untuk mengenal dan mempelajari teknologi modern. Sementara itu, bertambah parahnya keadaan dalam negeri Kekaisaran Tiongkok serta melemahnya kekuasaan Dinasti Qing juga berdampak pada kehidupan etnis Tionghoa di luar Tiongkok.

Menurunnya wibawa Pemerintah Dinasti Qing menyebabkan etnis Tionghoa di luar Tiongkok tersebut mengalami diskriminasi dan ketidakadilan dari pihak penguasa dan masyarakat di mana mereka menetap. Hal ini menimbulkan perasaan antipati di kalangan etnis Tionghoa ini terhadap Pemerintah Dinasti Qing. Akibatnya banyak di antara mereka yang bergabung dengan dua kelompok yang menentang Pemerintah Dinasti Qing di Tiongkok, yaitu kaum reformis di bawah pimpinan Kang Youwei (康有 为) dan kaum revolusioner yang dipimpin Sun Yat-Sen (孙中山). Hubungan yang terjalin antara etnis Tionghoa di luar Tiongkok, tepatnya di kawasan "Laut Selatan" ini, dan kedua kelompok di atas bersifat saling menguntungkan. Bagi kaum reformis dan kaum revolusioner, etnis Tionghoa di wilayah "Laut Selatan" itu merupakan sumber modal bagi perjuangan mereka, baik secara moril, materiil, finansial, bahkan nyawa. Adapun bagi etnis Tionghoa itu sendiri, hubungan mereka dengan kedua kelompok di atas telah menumbuhkan kesadaran politik mereka sekaligus mengembangkan rasa cinta pada negeri leluhur mereka yaitu Tiongkok.

Situasi seperti inilah yang mendorong Pemerintah Dinasti Qing untuk mengubah kebijakannya terhadap etnis Tionghoa di luar Tiongkok, yaitu dari yang tadinya bersifat memusuhi menjadi bersifat mendekati. Mula-mula, pada tahun 1903, Pemerintah Dinasti Qing menetapkan empat buah kebijakan yang sifatnya melindungi dan memberikan pembinaan bagi etnis Tionghoa di luar Tiongkok. ${ }^{4}$ Namun, besarnya modal dana yang dimiliki etnis Tionghoa di luar Tiongkok serta keterlibatan mereka dalam perjuangan

${ }^{3}$ George L. Hicks, ed., Overseas Chinese Remmitances from Southeast Asia 1910-1940, Singapore: Select Books Pte Ltd. 1993. 252.

${ }^{4}$ Mao Qixiong, et.al., Zhongguo Qiaowu Zhengce Gaishu (Garis Besara Kebijakan Pemerintah Cina Mengenai Masalah Etnis Cina di Seberang Lautan; 中国侨务政策概述), Beijing: Zhongguo Huaqiao Chubanshe (中国华 侨出版社), Februari 1993. 46-50. 
kelompok-kelompok yang anti Pemerintah Dinasti Qing membuat pemerintah yang bersangkutan sadar akan pentingnya peran etnis Tionghoa tersebutbagi perbaikan kondisi dalam negeri Kekaisaran Tiongkok dan untuk memperkuat kembali kekuasaannya. Maka, untuk dapat mencapai tujuannya ini secara legal, Pemerintah Dinasti Qing menetapkan apa yang dikenal dengan Regulasi Kewarganegaraan Dinasti Qing pada tahun 1909. Pada dasarnya regulasi ini menyatakan bahwa semua orang Tionghoa, baik yang menetap di Tiongkok maupun di luar Tiongkok adalah rakyat Kekaisaran Tiongkok. ${ }^{5}$ Dengan adanya regulasi ini, Pemerintah Dinasti Qing berkuasa secara legal atas etnis Tionghoa di luar Tiongkok sehingga ia dapat memanfaatkan potensi-potensi yang mereka miliki secara legal pula.

Adanya regulasi kewarganegaraan ini tidaklah menimbulkan masalah hingga diberlakukannya Nederlands Onderdaanschap (Peraturan tentang Kekawulanegaraan Belanda Bukan Belanda) yang ditetapkan oleh Pemerintah Hindia-Belanda. Isi dari peraturan tersebut juga memberi hak secara legal pada Pemerintah Hindia-Belanda untuk mengklaim etnis Tionghoa di Hindia-Belanda sebagai rakyatnya. ${ }^{6}$ Dengan demikian Pemerintah Hindia-Belanda juga berhak memanfaatkan etnis Tionghoa di wilayah kekuasaannya untuk kepentingannya sendiri. Inilah titik awal munculnya masalah dwi kewarganegaraan etnis Tionghoa di Hindia-Belanda, yang kemudian dikenal sebagai Indonesia. Meskipun tercapai kesepakatan antara Pemerintah Hindia-Belanda dengan Pemerintah Dinasti Qing untuk mengatasi masalah ini melalui sebuah perjanjian yang disebut Consular Treaty 1911, ${ }^{7}$ soal dwi kewarganegaraan etnis Tionghoa di luar Tiongkok ini akan menguak kembali pada periode-periode berikutnya.

\section{LATAR BELAKANG DAN LAHIRNYA HUKUM KEWARGANEGARAAN REPUBLIK TIONGKOK}

Meletusnya Revolusi 1911 yang mengakibatkan jatuhnya kekuasaan Dinasti Qing pada tahun 1912 menandai dimulainya suatu babak baru dalam dunia politik Tiongkok. Tiongkok yang tadinya merupakan kekaisaran selama ribuan tahun lamanya kini berubah menjadi sebuah republik. Akibat ketidaksepakatan antara Sun Yat-Sen dan kelompok revolusionernya, kekuasaan politik di Tiongkok pasca-Revolusi 1911 jatuh ke tangan seorang Warlord yang bernama Yuan Shikai (1912-1916). Kontribusi yang diberikan etnis Tionghoa di kawasan "Laut Selatan" bagi perjuangan kelompok revolusioner dan

\footnotetext{
${ }^{5}$ Zhou Nanjing (周南京), Jing Wai Huaren Guoji Wenti Taolun Ji (Kumpulan Pembahasan Mengenai Kewarganegaraan Etnis Cina di Luar Cina; 境外华人国籍问题讨论辑), Hong Kong: Hong Kong Press for Social Sciences Ltd. 2005. 490.

${ }^{6}$ Badan Koordinasi Intelijen Negara, Pedoman Penyelesaian Masalah Cina di Indonesiam vol. 1, Jakarta: Badan Koordinasi Masalah Cina-BAKIN. 1979. 126-7.

7 Leo Suryadinata, Peranakan Chinese Politics in Java: 1917-1942, Singapore: Marshall Cavendish Academic. 2005. 16.
} 
bagi kepentingan dalam negeri Kekaisaran Tiongkok menyadarkan Yuan Shikai akan pentingnya peran etnis Tionghoa tersebut bagi kepentingan Republik Tiongkok dan juga bagi pemerintahannya sendiri. Untuk itu, Yuan Shikai mengeluarkan dua kebijakan mengenai etnis Tionghoa di luar Tiongkok. ${ }^{8}$ Pertama ialah membentuk suatu sistem administrasi yang khusus menangani perihal etnis Tionghoa di luar Tiongkok yang disebut dengan Qiaowu Ju (侨务局) (Biro Urusan Etnis Tionghoa di luar Tiongkok). Tugasnya antara lain memberi perlindungan bagi etnis Tionghoa yang dimaksud. Kedua ialah memberi perlindungan secara legal atas hak dan kepentingan etnis Tionghoa di luar Tiongkok, umumnya buruh, yang diutus Pemerintah Republik Tiongkok untuk ikut serta dalam Perang Dunia I (1914-1918) di Eropa. Sementara itu, kontribusi etnis Tionghoa di luar Tiongkok bagi pembangunan ekonomi Republik Tiongkok terus meningkat. Hal ini terlihat dari meningkatnya arus pengiriman dana remitensi ke Tiongkok serta meningkatnya investasi etnis Tionghoa di luar Tiongkok bagi pemenuhan kebutuhan hidup keluarga mereka dan pembangunan daerah asal mereka di Tiongkok. ${ }^{9}$

Setelah berakhirnya Pemerintahan Yuan Shikai dengan kematiannya pada tahun 1916, kekuasaan politik di Tiongkok beralih ke tangan Sun Yat-Sen. Mengenai etnis Tionghoa di luar Tiongkok, Sun Yat-Sen tetap mempertahankan kebijakan yang telah ditetapkan oleh para pendahulunya. Ini tampak dari tiga kebijakan yang dikeluarkannya. Intinya ialah bahwa meskipun etnis Tionghoa diberi kebebasan untuk menetap di luar Tiongkok, namun Pemerintah Republik Tiongkok tetap mengakui mereka sebagai individu-individu yang berkepribadian Tionghoa serta melindungi identitas, hak dan harta benda yang mereka miliki melalui Biro Urusan Etnis Tionghoa di luar Tiongkok maupun konsulat-konsulat Republik Tiongkok di negara-negara lain. ${ }^{10}$ Disamping itu, etnis Tionghoa tersebut juga dihimbau untuk menanamkan investasi di bidang industri dan perdagangan di Tiongkok. Maka selain memiliki fungsi di atas, Biro Urusan Etnis Tionghoa di luar Tiongkok juga berfungsi melindungi asosiasi dagang dan organisasi sosial etnis Tionghoa di luar Tiongkok, menangani pendidikan, mempelajari kewarganegaraan mereka, menghimbau mereka untuk turut terlibat dalam usaha industri dagang di Tiongkok serta membiarkan mereka untuk turut memilih anggota Majelis Permusyawaratan Rakyat Republik Tiongkok. ${ }^{11}$ Keputusan Pemerintahan Sun Yat-Sen untuk tetap mengklaim etnis Tionghoa di luar Tiongkok sebagai rakyat dan bagian dari bangsa Tionghoa didasarkan pada fakta bahwa keberhasilan Sun Yat-Sen dan kelompok revolusionernya dalam perjuangan mereka meruntuhkan Kekaisaran Tiongkok antara lain berkat adanya dukungan dari etnis Tionghoa di luar Tiongkok,

\footnotetext{
${ }^{8}$ Mao Qixiong, et.al., op.cit., 51-3.

${ }^{9}$ George L. Hicks, ed., op.cit., 146.

${ }^{10}$ Mao Qixiong, et.al., op.cit., 54-8.

${ }^{11}$ Mao Qixiong, et.al., ibid., 54-8.
} 
tepatnya di wilayah "Laut Selatan", terutama secara finansial. Respons etnis Tionghoa di luar Tiongkok terhadap kebijakan Pemerintah Republik Tiongkok ini bukan hanya terlihat dari kian meningkatnya pengiriman dana remitensi serta investasi di Tiongkok oleh etnis Tionghoa tersebut, tetapi juga dari bermunculannya sekolah-sekolah milik etnis Tionghoa di Hindia-Belanda yang berorientasi ke Tiongkok di sejumlah wilayah di Hindia-Belanda. ${ }^{12}$ Reaksi yang terakhir ini sangat dipengaruhi oleh "Gerakan 4 Mei" (Wu Si Yundong) (五四运动) tahun 1919 yang bertujuan membebaskan Tiongkok dari upayaupaya kekuatan Barat untuk menguasainya sekaligus memodernisasi negara tersebut.

Setelah kematian Sun Yat-Sen, Pemerintahan Republik Tiongkok dipimpin oleh Chiang Kai Shek (Jiang Jieshi) (蒋介石). Sebagaimana para pendahulunya, pemerintahan ini juga tetap ingin mempertahankan klaimnya atas etnis Tionghoa di luar Tiongkok, mengingat kontribusi serta peran mereka yang sangat berarti bagi kepentingan Tiongkok. Maka, langkah pertama yang diambil Pemerintahan Chiang Kai Shek ialah membentuk dua lembaga yang bertugas menangani urusan etnis Tionghoa di luar Tiongkok. ${ }^{13}$ Lembaga yang pertama ialah Komite Urusan Luar Negeri (Hai Wai Gongzuo Weiyuanhui) (海外工作委员会) yang tugasnya antara lain mempropagandakan agenda politik Partai Nasionalis Tiongkok (Guomindang) (国民党) di kalangan etnis Tionghoa di luar Tiongkok ${ }^{14}$. Lembaga yang kedua ialah Badan Administratif Urusan Etnis Tionghoa di luar Tiongkok. Guna mempertegas klaimnya atas etnis Tionghoa di luar Tiongkok secara yuridis, maka pada 5 Februari 1929, Pemerintahan Chiang Kai-Shek mempromulgasikan Hukum Kewarganegaraan Republik Tiongkok. Seperti halnya Regulasi Kewarganegaraan Dinasti Qing, artikel II hukum kewarganegaraan ini pada dasarnya menyatakan bahwa semua orang Tionghoa, di mana pun mereka menetap, adalah warga negara Tiongkok. ${ }^{15}$

Ternyata Hukum Kewarganegaraan Republik Tiongkok ini diberlakukan seiring dengan terjadinya depresi ekonomi dunia. Krisis ini memaksa etnis Tionghoa di luar Tiongkok untuk semakin menggencarkan investasi serta pengiriman dana remitensi ke Tiongkok agar dapat memanfaatkan modal finansial yang mereka miliki secara lebih optimal. Melihat meningkatnya keinginan etnis Tionghoa di luar Tiongkok untuk mencari untung di Tiongkok serta adanya rasa keterikatan mereka pada negeri leluhur, Pemerintah Republik Tiongkok memanfaatkan kesempatan ini untuk kian memperdalam rasa cinta pada negeri leluhur di kalangan etnis Tionghoa di luar Tiongkok. Caranya antara lain dengan mengontrol sekolah-sekolah milik etnis Tionghoa di luar Tiongkok, mengirimkan

\footnotetext{
12 “ He Yin Huaqiao Jiayu Jian (Surevei Mengenai Pendidikan Etnis Cina di Luar Cina di Hindia Belanda; 荷 印华侨教育鉴), Mei 1928, hal. 449-454, yang dikutip oleh Cai Renlong (蔡仁龙), et.al., Yindunixiya Huaqiao Shi (Sejarah Etnis Cina di Luar Cina Di Indonesia; 印度尼西亚华侨史), Beijing: Haiyang Chubanshe (海洋 出版社). 1985. 454.

${ }^{13}$ Mao Qixiong, et.al., op.cit., 58.

${ }^{14}$ Mao Qixiong, et.al., ibid., 58.

${ }^{15}$ Zhou Nanjing (周南京), op.cit., 507.
} 
tenaga pengajar dan bahan ajar ke sekolah-sekolah tersebut, mengutus kader-kader Partai Nasionalis Tiongkok untuk merekrut dan mengorganisir etnis Tionghoa di luar Tiongkok. Pemerintah Republik Tiongkok bahkan mendorong etnis Tionghoa tersebut untuk turut terlibat dalam perpolitikan di Tiongkok. ${ }^{16}$ Upaya Pemerintah Republik Tiongkok ini ternyata tidaklah sia-sia. Pada waktu Tiongkok diduduki oleh Jepang, dana remitensi dari etnis Tionghoa di luar Tiongkok yang masuk ke Tiongkok kian meningkat ${ }^{17}$ sehingga perekonomian Tiongkok masih dapat terselamatkan. Di samping itu, mengalir pula bantuan dana, materi, serta tenaga sukarelawan dari etnis Tionghoa di luar Tiongkok ke Tiongkok guna mempertahankan negeri leluhur mereka dari serangan Jepang. Faktor besarnya dukungan yang diberikan etnis Tionghoa di luar Tiongkok ini bagi negeri leluhur mereka, selain besarnya potensi yang mereka miliki bagi kepentingan Tiongkok inilah yang membuat Pemerintahan Mao Zedong (毛泽东) dengan Partai Komunisnya tetap mengklaim etnis Tionghoa tersebut sebagai warga negara sekaligus bagian dari bangsa Tionghoa.

\section{LATAR BELAKANG DAN LAHIRNYA UNDANG-UNDANG KEWARGANEGARAAN RRT 1980}

Kemenangan Partai Komunis Tiongkok (Gongchandang) (共产党) dalam perjuangan mereka melawan Partai Nasionalis Tiongkok ditandai dengan didirikannya Republik Rakyat Tiongkok (RRT) pada 1 Oktober 1949. Kehancuran di berbagai kehidupan yang dialami Tiongkok pada saat itu akibat serangan kekuatan asing dan perang saudara antara kedua partai di atas menyebabkan Pemerintah RRT kembali berpaling pada etnis Tionghoa di luar Tiongkok sebagai salah satu sumber modal pembangunan dalam negerinya. Ini terlihat dari isi pidato komisioner utama Komisi Urusan Etnis Tionghoa di luar Tiongkok Pemerintah Pusat Komunis Tiongkok (Huaqiao Shiwu Weiyuanhui) (华侨事务委员会), yaitu He Xiangning pada Perayaan Tahun Baru Imlek Tionghoa (Xinjia) (新家) tahun 1950.. ${ }^{18}$ Komisi yang diketuai He Xiangning ini berkedudukan setara dengan kementerian dan cabang-cabangnya tersebar di berbagai wilayah di Tiongkok. Pembentukan komisi ini merupakan salah satu langkah Pemerintah RRT untuk mencari dukungan di kalangan

\footnotetext{
${ }^{16}$ Leo Suryadinata, Chinese and Nation-Building in Southeast Asia, Singapore: Marshall Cavendish International Private Limited. 2004. 118.

${ }^{17}$ Lin Jinzhi (林金枝), Lun Liang Ci Shijie Da Zhan Qijian Dongnanya Huaqiao Dui Zhongguo Shehui Jingji Fazhan de Zuoyong (Pembahasan Mengenai Peran Etnis Cina di Luar Cina Terhadap Perkembangan Perekonomian dan Kemasyarakatan Cina di Antara Dua Perang Dunia; 论两次世界大战期间东南亚华侨 对中国社会经济发展的作用) dalam Ng Lun Ngai-ha, et.al., Liang Ci Shijie Da Zhan Qijian Zai Dong Zhou zhi Hai Wai Huaren (Etnis Cina di Luar Cina yang Ada di Asia Timur Antara Dua Perang Dunia; 两次世界 大战期间东洲之海外华人), Hongkong: The Chinese University of Hong Kong. 1989. 124.

${ }^{18}$ United Book Store (联合书店), 'Regulations on Overseas Chinese Affairs' (侨务法令), Book I, dalam Communist China Problem Research Series, '12 Programs of Communist China for Overseas Chinese', Hong Kong: The Union Research Institute. 1956. 15.
} 
etnis Tionghoa di luar Tiongkok bagi kepentingan RRT. Langkah lainnya ialah dengan tetap memberlakukan Hukum Kewarganegaraan Republik Tiongkok 1929. Agar etnis Tionghoa di luar Tiongkok tergerak untuk turut berkontribusi dalam pembangunan RRT, Pemerintah RRT pun berjanji akan melakukan upaya maksimal untuk melindungi hak legal dan kepentingan etnis Tionghoa di luar Tiongkok. ${ }^{19}$ Di samping itu, seperti halnya para pendahulunya, Pemerintah RRT juga berusaha menanamkan serta meningkatkan rasa keterikatan etnis Tionghoa di luar Tiongkok pada negeri leluhur mereka. Upayaupaya Pemerintah RRT untuk melibatkan etnis Tionghoa di luar Tiongkok dalam pembangunan dalam negerinya menimbulkan ketidaksenangan dan kecurigaan di antara bangsa-bangsa di wilayah "Laut Selatan" yang pada waktu itu sudah menjadi negara-negara merdeka dan berdaulat. Maka, sejak saat itu, wilayah ini dikenal sebagai Asia Tenggara. Pemerintah di negara-negara Asia Tenggara khawatir dan curiga bahwa etnis Tionghoa yang menetap di wilayah kekuasaan mereka akan dimanfaatkan oleh Pemerintah RRT untuk menyebarluaskan paham komunis di kawasan Asia Tenggara yang pada umumnya non komunis, bahkan ada yang antikomunis. Timbulnya sentimen tersebut disebabkan oleh faktor ideologi yang dianut Pemerintah RRT dan kecenderungan politik luar negerinya pada Uni Soviet. Guna mencegah dimanfaatkannya etnis Tionghoa di Asia Tenggara oleh Pemerintah RRT, Pemerintah negara-negara Asia Tenggara, terutama Indonesia, berusaha meminimalkan keterikatan etnis Tionghoa tersebut pada negeri leluhur mereka dengan melarang didirikannya sekolah-sekolah Tionghoa yang berorientasi ke RRT.

Kecurigaan Pemerintah negara-negara Asia Tenggara terhadap kebijakan Pemerintah RRT disertai gagalnya gerakan komunis di wilayah tersebut membuat Pemerintah RRT mengkaji ulang kebijakannya terhadap etnis Tionghoa di luar Tiongkok. Ia menyadari jika kebijakannya terhadap etnis Tionghoa di luar Tiongkok tetap diteruskan, hal itu akan merusak hubungannya dengan Pemerintah negara-negara Asia Tenggara. Rusaknya hubungan ini akan berdampak pada dua hal. Pertama ialah terancamnya keamanan wilayah RRT sebagai negara berdaulat. Kedua ialah tertutupnya kesempatan bagi Pemerintah RRT untuk membentuk aliansi dengan negara-negara Asia Tenggara, yang menyatakan diri netral atau tidak berpihak, guna membendung tersebarnya pengaruh Amerika Serikat (AS) di kawasan Asia Tenggara. Pemerintah RRT khawatir jika kebijakannya terhadap etnis Tionghoa di luar Tiongkok tidak dikaji ulang, Pemerintah negara-negara Asia Tenggara akan bergabung dengan AS untuk menghadapi komunis di Asia. Atas dasar pertimbangan inilah, akhirnya Pemerintah RRT memutuskan untuk menyelesaikan masalah etnis Tionghoa di luar Tiongkok ini dengan Pemerintah

\footnotetext{
19 'Zhongguo Renmin Zhengzhi Xiehuiyi Gongtong Gangling' (Program Bersama Konferensi Permusyawaratan Politik Cina; 中国人民政治协会仪共同纲领), Renmin Shouce (人民手册) 1951 (1951 People's Handbook), section 3, hal. 9, dalam A. Dahana, "The Evolution of China's Policy Toward Malaysia Since 1949", disertasi yang tidak diterbitkan, Honolulu: University of Hawaii at Manoa. Mei 1986. 65.
} 
negara-negara Asia Tenggara yang punya hubungan diplomatik dengan RRT. Sebagai langkah awal, ditandatanganilah Perjanjian Dwi Kewarganegaraan antara Pemerintah Republik Indonesia (RI) dengan Pemerintah RRT di Bandung (Indonesia) pada 22 April 1955. Inti dari isi perjanjian ini ialah bahwa etnis Tionghoa di Indonesia bebas memilih kewarganegaraannya. Dengan demikian, etnis Tionghoa di Indonesia tidak lagi berkewarganegaraan rangkap sehingga Pemerintah RRT tidak lagi mempunyai dasar yang kuat untuk memanfaatkan potensi-potensi yang dimiliki etnis Tionghoa tersebut bagi kepentingan RRT.

Niat Pemerintah RRT untuk tidak lagi memanfaatkan etnis Tionghoa di luar Tiongkok demi kepentingan RRT tampak dari isi pidato He Xiangning, Ketua Komite Urusan Tionghoa Perantauan, dalam Konggres Rakyat Nasional RRT pada 6 Februari 1958. ${ }^{20}$ Namun dalam kenyataannya, Pemerintah RRT masih tetap berupaya agar etnis Tionghoa turut berkontribusi dalam pembangunan RRT dengan menetapkan kebijakankebijakan yang bersifat mengakomodasi aneka kebutuhan dari keluarga-keluarga etnis Tionghoa di luar Tiongkok yang berdomisili di RRT (qiaojuan) (侨眷). Harapan Pemerintah RRT ialah bahwa melihat keluarga mereka di RRT mendapat perlakuan baik dari Pemerintah RRT, etnis Tionghoa di luar Tiongkok akan kembali tergerak untuk memberikan kontribusi bagi kepentingan RRT.

Pada tahun 1966-1976, kekuasaan politik di RRT jatuh ke tangan kelompok komunis radikal yang lebih mementingkan keunggulan ideologis daripada kepentingan di bidang-bidang lainnya. Pemerintah RRT pada masa itu mengimbau dunia untuk bangkit dan berjuang bersama guna melawan "imperialisme AS" dengan bersenjatakan pemikiran Mao Zedong. ${ }^{21}$ Maka, muncullah kebijakan-kebijakan radikal di berbagai bidang, termasuk kebijakan tentang etnis Tionghoa di luar Tiongkok. Kebijakan seperti inilah yang menyebabkan terjadinya demonstrasi-demonstrasi massa oleh etnis Tionghoa pro-Pemerintah RRT di sejumlah negara Asia Tenggara, termasuk di Indonesia antara 1966-1969. Melihat gejala seperti ini, kecurigaan bahwa etnis Tionghoa di luar Tiongkok kembali dimanfaatkan Pemerintah RRT untuk menyebarluaskan paham komunis, kembali muncul di kalangan Pemerintah negara-negara Asia Tenggara. Faktor inilah yang mendorong Pemerintah RI untuk menghentikan diberlakukannya Perjanjian Dwi Kewarganegaraan RI-RRT secara sepihak pada tahun 1969.

Masalah dwi kewarganegaraan etnis Tionghoa di luar Tiongkok ini tidak banyak dibicarakan hingga naiknya Deng Xiaoping (邓小平), seorang tokoh Partai Komunis Tiongkok berhaluan moderat, ke tampuk Pemerintahan RRT pada tahun 1977. Pada saat itu, kondisi dalam negeri RRT serba buruk dan tidak menentu sebagai akibat dari

\footnotetext{
${ }_{20}$ "Tionghoa Perantauan WN Tiongkok harus Taati Hukum dan Peraturan-peraturan Negeri Tempat

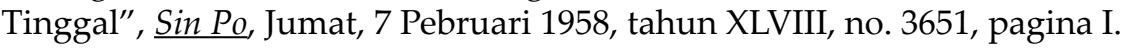

${ }^{21}$ A. Dahana, op.cit., 72.
} 
berbagai kebijakan radikal yang diterapkan pendahulunya. Untuk dapat memperbaiki keadaan dalam negeri RRT ini, Deng Xiaoping mengadakan gerakan "Reformasi dan Keterbukaan" (Gaige Kaifang) (改革开放). Salah satu kebijakan yang dikeluarkan Deng Xiaoping berkaitan dengan gerakan di atas ialah "Empat Modernisasi", yaitu kebijakan yang menetapkan diadakannya modernisasi dalam bidang pertanian, industri, ilmu pengetahuan dan teknologi, serta bidang pertahanan. Untuk itu, lagi-lagi Pemerintah RRT membutuhkan bantuan dari berbagai pihak, termasuk dari etnis Tionghoa di luar Tiongkok. Sebab di mata Pemerintah RRT, keberadaan etnis Tionghoa di luar Tiongkok membuka kesempatan bagi mereka untuk dapat mempelajari serta menyerap hal-hal yang sangat diperlukan RRT agar dapat membangun kembali negaranya, tetapi yang tidak dimiliki oleh etnis Tionghoa di Tiongkok. Adapun hal-hal yang dimaksud ialah keahlian teknologi modern, kemampuan manajemen, modal finansial serta jaringan relasi di dunia internasional. Atas dasar inilah, Deng Xiaoping memutuskan untuk mengadakan pertemuan dengan delegasi etnis Tionghoa di luar Tiongkok di akhir tahun 1977. Pertemuan ini selain menghasilkan imbauan agar etnis Tionghoa di luar Tiongkok membentuk "Front Persatuan" di antara mereka, juga menyatakan bahwa sekalipun telah diberi kebebasan untuk dapat memilih kewarganegaraannya sendiri, mereka tetap dianggap sebagai "famili (kinfolk) dan teman" (qinqi pengyou)(亲戚朋友) dari bangsa Tionghoa. ${ }^{22}$ Artinya etnis Tionghoa di luar Tiongkok yang sudah menjadi warga negara dari negara di mana mereka menetap tetap dianggap Pemerintah RRT sebagai bagian dari bangsa Tionghoa.

Cara pandang Pemerintah RRT tentang etnis Tionghoa di luar Tiongkok ini kembali menimbulkan kecurigaan di kalangan Pemerintah negara-negara Asia Tenggara bahwa etnis Tionghoa tersebut akan kembali dimanfaatkan oleh Pemerintah RRT untuk menyebarluaskan paham komunis di kawasan Asia Tenggara. Deng Xiaoping mendeteksi adanya sentimen ini ketika ia melakukan kunjungan kenegaraan ke Asia Tenggara tahun 1978 untuk kembali menjalin serta membina hubungan baik dengan negaranegara di kawasan tersebut. Kunjungan ini ia lakukan bukan hanya demi kepentingan RRT saja, tetapi juga demi kepentingan etnis Tionghoa di luar Tiongkok itu sendiri. Di dalam kunjungan ini pula, Deng Xiaoping baru menyadari bahwa banyak di antara etnis Tionghoa di Asia Tenggara yang tidak lagi mengidentifikasikan dirinya sebagai bagian dari bangsa Tionghoa, melainkan sebagai bagian dari bangsa di negara di mana mereka menetap. Maka, untuk mendapatkan kembali kepercayaan negara-negara Asia Tenggara demi kepentingan semua pihak yang terkait di dalamnya, Pemerintah RRT menetapkan sebuah Undang-Undang Kewarganegaraan yang disebut sebagai

\footnotetext{
${ }_{22}^{22}$ Kinfolk' merupakan terjemahan resmi dalam Bahasa Inggris, yang digunakan dalam Beijing Review. Kataaslinya ialah 'qinqi', yang artinya famili. Peking Review, no. 3 (20 Januari 1978), hal. 16, dalam Leo Suryadinata, Chinese and The ASEAN States: The Ethnic Chinese Dimension, Singapore: Singapore University Press. 70.
} 
Undang-Undang Kewarganegaraan RRT (1980). Pada dasarnya isi Undang-Undang ini menyatakan bahwa Pemerintah RRT tidak lagi mengakui adanya dwi kewarganegaraan dan bahwa etnis Tionghoa yang telah menjadi warga negara dari negara lain (bukan RRT) atas kemauan sendiri atau melalui naturalisasi, bukan lagi warga negara RRT. ${ }^{23}$ Dikeluarkannya Undang-Undang Kewarganegaraan ini menandai berakhirnya masalah dwikewarganegaraan etnis Tionghoa di luar Tiongkok yang terus-menerus menjadi sumber ketegangan antara Pemerintah RRT dengan Pemerintah negara-negara Asia Tenggara, khususnya Indonesia.

Meskipun masalah dwikewarganegaraan etnis Tionghoa di luar Tiongkok itu sudah tidak eksis lagi, ternyata niat Pemerintah RRT untuk memanfaatkan etnis Tionghoa tersebut bagi kepentingan RRT masih terus berlanjut. Hal ini disebabkan oleh meningkatnya globalisasi ekonomi di dunia internasional yang turut mendorong meningkatnya kebutuhan RRT akan modal dana, keahlian dan ketrampilan di berbagai bidang kehidupan demi terlaksananya modernisasi di negara tersebut. Maka, untuk kesekian kalinya, Pemerintah RRT kembali berpaling pada etnis Tionghoa di luar Tiongkok untuk memperoleh bantuan yang diperlukannya. Agar tujuan ini dapat tercapai, Pemerintah RRT berusaha menjalin hubungan baik dengan famili dari etnis Tionghoa di luar Tiongkok yang menetap di RRT. Ada empat langkah konkret yang ditempuh Pemerintah RRT untuk mewujudkan maksudnya ini. Pertama ialah membentuk China Federation of Returned Overseas Chinese (ACF ROC) yang bertugas melindungi famili dari etnis Tionghoa di luar Tiongkok yang menetap di RRT. Kedua ialah memberi kesempatan bagi etnis Tionghoa di luar Tiongkok untuk menelusuri kembali jejak leluhur mereka di RRT. Ketiga ialah memberi kesempatan pada etnis Tionghoa di luar Tiongkok untuk membangun daerah asal mereka di RRT. Keempat ialah menghimbau etnis Tionghoa di luar Tiongkok untuk mengirimkan dana remitensi dan memberikan donasi ke RRT sekaligus menanam investasi disana. ${ }^{24}$ Langkah-langkah yang diambil Pemerintah RRT ini memang menghasilkan buah. Namun, seiring dengan kian meningkatnya globalisasi ekonomi dunia pada periode 1990 hingga kini, modal yang diperoleh Pemerintah RRT ternyata tidak dapat mencukupi modal yang ia butuhkan bagi pelaksanaan modernisasi di negaranya. Guna memenuhi kebutuhan modal yang kian membesar jumlahnya itu, Pemerintah RRT kembali mendekati etnis Tionghoa di luar Tiongkok dengan keyakinan bahwa etnis Tionghoa tersebut akan bersedia untuk turut berkontribusi dalam pembangunan RRT. ${ }^{25}$ Namun kali ini, cara pendekatan yang digunakan Pemerintah RRT

\footnotetext{
${ }^{23}$ Liu Shudan (刘树赕) \& Li Weiping (李伟萍), ed., Zhonghua Renmin Gongheguo Fadian ( Law of the People's Republic of China; 中华人民共和国法典), Jilin (吉林): Jilin Renmin Chubanshe (吉林人民出版社), 1 Mei 2000.56-8.

${ }^{24}$ Mette Thuno, "Reaching Out and Incorporating Chinese Overseas: The Trans-territorial Scope of the PRC by the End of the $20^{\text {th }}$ Century", dalam The China Quartely, Desember 2001, no. 168, 918.

${ }^{25}$ Zhu Chanxian (朱阐贤), 'Shi Tan Deng Xiaoping Dui Hai Wai Huaqiao de Zhongyao Lunshu' (Membahas
} 
berbeda dengan sebelumnya.

Pendekatan terhadap etnis Tionghoa di luar Tiongkok tidak hanya dilakukan melalui famili mereka yang menetap di RRT, melainkan menjangkau sasaran yang dimaksud secara langsung. Tindakan konkretnya ialah dengan mengirimkan tenagatenaga pengajar dan bahan ajar Bahasa Mandarin ke sejumlah negara di dunia, mengadakan pelatihan di RRT bagi tenaga-tenaga pengajar asing serta mengirimkan delegasi untuk melakukan kunjungan ke etnis Tionghoa di luar Tiongkok, yang bergerak di bidang pendidikan, perbankan, industri dan bisnis. Ternyata upaya-upaya Pemerintah RRT ini tidaklah sia-sia karena pada periode 1990 ke atas, investasi asing dari negaranegara Asia Tenggara yang didominasi oleh para pengusaha etnis Tionghoa di kawasan tersebut meningkat drastis. ${ }^{26}$ Meskipun pada paruh kedua periode 1990-an Pemerintah RRT mulai mengalihkan perhatiannya pada etnis Tionghoa yang menetap di Amerika Utara sebagai sumber modal bagi pembangunan dalam negerinya, kontribusi etnis Tionghoa di Asia Tenggara tetap signifikan bagi kepentingan RRT .

\section{PENUTUP}

Dwi kewarganegaraan etnis Tionghoa di luar Tiongkok merupakan suatu isu yang kerap menimbulkan benturan antara kepentingan Pemerintah Tiongkok dengan Pemerintah negara-negara di Asia Tenggara, terutama dengan Pemerintah Indonesia. Namun, jika meninjau sejarah hubungan antara Pemerintah Tiongkok dengan etnis Tionghoa di luar Tiongkok, nampak bahwa faktor penyebab timbulnya masalah dwi kewarganegaraan etnis Tionghoa ini bukan terletak pada konsep kewarganegaraan itu sendiri. Masalahnya terletak pada cara pandang Pemerintah Tiongkok yang hingga kini menganggap bahwa etnis Tionghoa, di mana pun mereka berada dan apapun kewarganegaraan mereka, adalah bagian integral dari bangsa Tionghoa karena adanya faktor keterikatan budaya. Cara pandang seperti inilah yang mendasari upaya-upaya Pemerintah Tiongkok untuk terus-menerus menghimbau etnis Tionghoa di luar Tiongkok untuk turut berkontribusi dalam membangun dan memajukan negara Tiongkok. Masalah dwi kewargangeraan etnis Tionghoa di luar Tiongkok ini akan selalu menjadi masalah laten, terutama di Indonesia, selama tidak terjadi perubahan dalam cara pandang Pemerintah Tiongkok terhadap etnis Tionghoa tersebut.

Pembicaraan Penting Deng Xiaoping terhadap Etnis Cina Warganegara RRC yang Merantau Sementara ke Negara Lain; 试谈邓小平对海外华侨的重要论述), dalam Zhou Wanglin (周望林), ed., Huaqiao Huaren Yanjiu Luncong (Kumpulan Penelitian Mengenai Etnis Cina di Luar Cina; 华侨华人研究论丛), Beijing; Zhongguo Huaqiao Chubanshe (中国华侨出版社). 1998. 33.

${ }^{26}$ Guo Liang (郭梁), Dongnanya Huaqiao Huaren Jingji Jianshi (Sejarah Ringkas Perekonomian Etnis Cina di Luar Cina di Asia Tenggara; 东南亚华侨华人经济坚实), Beijing: Jingji Kexue Chubanshe (经济科学出版 社). 1998. 228. 


\section{DAFTAR ACUAN}

Badan Koordinasi Intelijen Negara. Pedoman Penyelesaian Masalah Cina di Indonesiam vol. 1, Jakarta: Badan Koordinasi Masalah Cina-BAKIN, 1979.

Cai, Renlong (蔡仁龙), et.al. Yindunixiya Huaqiao Shi (Sejarah Etnis Cina di Luar Cina Di Indonesia; 印度尼西亚华侨史), Beijing: Haiyang Chubanshe (海洋出版社), 1985.

China. Chinese History. Beijing: China Reconstructs Press, 1988.

The China Quartely, no. 168, Desember 2001.

Communist China Problem Research Series. "12 Programs of Communist China for Overseas Chinese", Hong Kong: The Union Research Institute, 1956.

Dahana, A. "The Evolution of China's Policy Toward Malaysia Since 1949", disertasi untuk mencapai gelar Doctor of Philosophy dalam bidang Sejarah dari University of Hawaii at Manoa: 1986.

Guo, Liang (郭梁). Dongnanya Huaqiao Huaren Jingji Jianshi (Sejarah Ringkas Perekonomian Etnis Cina di Luar Cina di Asia Tenggara; 东南亚华侨华人经济坚实), Beijing: Jingji Kexue Chubanshe (经济科学出版社), 1998.

Hicks, George L., ed. Overseas Chinese Remmitances from Southeast Asia 1910-1940, Singapore: Select Books Pte Ltd., 1993.

Hooker, M. Barry., ed. Law and the Chinese in Southeast Asia. Singapore: Institute of Southeast Asian Studies, 2002.

Lee, Lai To, ed. The 1911 Revolution - The Chinese in British and Dutch Southeast Asia. Singapore: Heinemann Publishers Asia Pte Ltd, 1987.

Lin, Lisheng. Dongnanya Huaren yu Zhongguo Jingji yu Shehui (Etnis Cina di Luar Cina di Asia Tenggara dan Masyarakat serta Perekonomian Cina). Singapore: Dongzhou Yanjiu Xuehui Congshu, 1994.

Liu, Shudan (刘树赕) \& Li Weiping (李伟萍), ed., Zhonghua Renmin Gongheguo Fadian ( Law of the People's Republic of China; 中华人民共和国法典), Jilin (吉林): Jilin Renmin Chubanshe (吉林人民出版社), Mei 2000.

Sin Po. "Tionghoa Perantauan WN Tiongkok harus Taati Hukum dan Peraturan-peraturan Negeri Tempat Tinggal", Jumat, 7 Pebruari 1958, tahun XLVIII, no. 3651, pagina I.

Suryadinata, Leo. China and The ASEAN States: The Ethnic Chinese Dimension. Singapore: Sinagpore University Press, 1985.

. Chinese and Nation-Building in Southeast Asia, Singapore: Marshall

Cavendish International Private Limited, 2004.

. Peranakan Chinese Politics in Java: 1917-1942, Singapore: Marshall

Cavendish Academic, 2005.

Wang, Gungwu. Community and Nation: China, Southeast Asia and Australia, Allen \& Unwin Pty, Ltd., 1992. 
Zhou, Nanjing (周南京). Jing Wai Huaren Guoji Wenti Taolun Ji (Kumpulan Pembahasan Mengenai Kewarganegaraan Etnis Cina di Luar Cina; 境外华人国籍问题讨论辑), Hong Kong: Hong Kong Press for Social Sciences Ltd., 2005.

Zhou, Wanglin (周望林), ed. Huaqiao Huaren Yanjiu Luncong (Kumpulan Penelitian Mengenai Etnis Cina di Luar Cina; 华侨华人研究论丛), Beijing; Zhongguo Huaqiao Chubanshe (中国华侨出版社), 1998. 